\title{
Thymus pathology in myasthenia gravis with anti- acetylcholine receptor antibodies and concomitant Hashimoto's thyroiditis. A four-case series and literature review
}

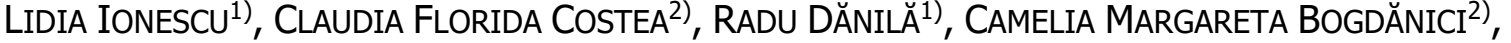 \\ DRAGOŞ VIOREL SCRIPCARIU ${ }^{3)}$, ROXANA MARIA LIVĂDARIU ${ }^{11}$, GABRIELA FLORENTJA DUMITRESCU ${ }^{4}$, \\ CRISTINA MARIA GAVRILESCU ${ }^{5}$, RALUCA Alina DRAGOMIR ${ }^{6}$, , ANCA SAVA ${ }^{4,7)}$, ANDREI IONUT CUCU ${ }^{8}$,

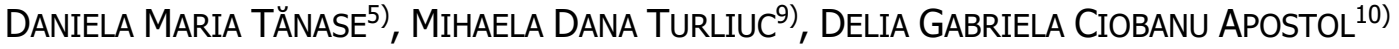

\begin{abstract}
1) Department of Surgery, Faculty of Medicine, Grigore T. Popa University of Medicine and Pharmacy, Iaşi, Romania
2) Department of Ophthalmology, Faculty of Medicine, Grigore T. Popa University of Medicine and Pharmacy, Iaşi, Romania

3) Department of General Surgery, Faculty of Medicine, Grigore T. Popa University of Medicine and Pharmacy, Iaşi, Romania

4) Department of Pathology, Prof. Dr. Nicolae Oblu Emergency Clinical Hospital, Iaşi, Romania

5) Department of Internal Medicine, Faculty of Medicine, Grigore T. Popa University of Medicine and Pharmacy, Iaşi, Romania

${ }^{6)}$ Department of Anesthesiology and Oral Surgery, Faculty of Medicine, Grigore T. Popa University of Medicine and Pharmacy, Iaşi, Romania

7)Department of Anatomy, Faculty of Medicine, Grigore T. Popa University of Medicine and Pharmacy, Iaşi, Romania

${ }^{8)}{ }^{\text {IId }}$ Clinic of Neurosurgery, Prof. Dr. Nicolae Oblu Emergency Clinical Hospital, Iaşi, Romania

9) Department of Neurosurgery, Faculty of Medicine, Grigore T. Popa University of Medicine and Pharmacy, Iaşi, Romania

${ }^{10)}$ Department of Morpho-Functional Sciences I, Grigore T. Popa University of Medicine and Pharmacy, Iaşi, Romania
\end{abstract}

\begin{abstract}
Objective: Identifying the morphological features of thymus in patients with myasthenia gravis (MG) with anti-acetylcholine receptor (AChR) antibodies and concomitant Hashimoto's thyroiditis (HT), which were recruited from a single surgical unit of a tertiary referral hospital located in the North-Eastern region of Romania, over a period of 11 years. Patients, Materials and Methods: We retrospectively reviewed clinical, imaging, laboratory, thymic pathology, and outcome data that were obtained from medical records of patients with MG and concomitant $\mathrm{HT}$, to whom a thymectomy was performed for a suspected thymic lesion. All the surgical interventions were done in the Third Clinic of Surgery, St. Spiridon Emergency County Hospital, laşi, Romania, for an 11 years' period, i.e., from January 1, 2000 and December 31, 2010. Results: Four patients (three females and one male) were included. The mean age of the patients at the time of their thymectomy was 40.25 years. Of all patients, $75 \%$ had moderate or severe MG, $100 \%$ had anti-AChR antibodies, and an electromyographic decrement greater than $25 \%$. All patients have been diagnosed with $\mathrm{HT}$ in their past medical history by a full thyroid panel [high thyroid-stimulating hormone (TSH) values, low free thyroxine (fT4) values, and the presence of the anti-thyroid antibodies] and all of them have been treated with Euthyrox. Our four patients expressed different MG subtypes, each of them being associated with different thymus pathology. Thoracic computed tomography (CT) scan revealed heterogeneous mediastinal masses and established the correct diagnosis only in $25 \%$ of cases. The pathological exams also revealed a heterogeneous pattern of thymic lesions. In contrast with other studies, our patients with MG with anti-AChR antibodies and concomitant HT presented atrophic thymus more frequently (50\%), but with particular morphological changes of Hassall's corpuscles. Also, $25 \%$ of cases were diagnosed with thymic lympho-follicular hyperplasia (TLFH) associated with thymic epithelial hyperplasia. In B2 thymoma, neoplastic epithelial cells expressed cytokeratin 19 (CK19) immunoreactivity, high Ki67 labeling index and strong p63 immunopositivity. Conclusions: In our series, MG and HT occurred simultaneously, or one of them was diagnosed before the other, raising some new questions regarding the immune mechanism of these two autoimmune diseases. Due to the heterogeneous morphological changes of the thymus that we found in this study, we can hypothesize that thymus is involved in the pathogenic mechanism of $M G$ with anti-AChR-antibodies and concomitant HT development.
\end{abstract}

Keywords: myasthenia gravis, thymectomy, Hashimoto's thyroiditis, immunohistochemistry, thoracic computed tomography scan, anti-acetylcholine receptor (AChR) antibody.

\section{$\sim$ Introduction}

Myasthenia gravis (MG) is an autoimmune antibodymediated disease that affects the neuromuscular junction in different groups of muscles or in all skeletal muscles.
Due to immune attacks against various proteins of the postsynaptic membrane the nicotinic acetylcholine receptor (AChR), the muscle-specific tyrosine kinase (MuSK) or the low-density lipoprotein receptor-related protein 4 (LRP4), agrin, tytin, ryanodine receptors, the disease manifests

This is an open-access article distributed under the terms of a Creative Commons Attribution-NonCommercial-ShareAlike 4.0 International Public License, which permits unrestricted use, adaptation, distribution and reproduction in any medium, non-commercially, provided the new creations are licensed under identical terms as the original work and the original work is properly cited. 
itself as fatigability and weakness of ocular, facial, oropharyngeal, limb and respiratory muscles [1].

MG is included among rare diseases, having an estimated prevalence of 7.77 per 100000 individuals [2].

So far, the origin of autoimmune dysfunction in patients with MG remains unknown; however, thymic abnormalities and the consecutive immunological deficits play important roles in patients with anti-AChR antibodies. Some authors highlighted the fact that there are genetic and hormonal components associated with the production of antibodies [3].

Over time there have been many classifications of $\mathrm{MG}$, but the clinical severity of the disease has been currently assessed based on the Myasthenia Gravis Foundation of America (MGFA) classification [4] into five main classes. Recently, Koneczny \& Herbst (2019) classified MG into 10 subtypes according to clinical characteristics, types of detected antibody, and thymus pathology [5]. This classification reveals a great variability of $\mathrm{MG}$ and, as such, it becomes a challenge for all clinicians, as well as for surgeons.

Nonetheless, the most important fact in the management of patients with MG is the risk of developing another autoimmune disease [6]. Such patients can later develop an autoimmune thyroid disease (ATD), i.e., Graves' disease or Hashimoto's disease, but there are also rare cases with a second development of autoimmune hemolytic anemia [7] systemic lupus erythematosus [8], and rheumatoid arthritis [9]. ATD was the most frequent of 23 associated autoimmune disorders, occurring in $10 \%$ of MG patients [6].

The exact pathogenesis, trigger factors and genetic mechanism of MG, as well as MG in relation with other autoimmune disorders are still unknown [6].

Chronic autoimmune thyroiditis, or Hashimoto's thyroiditis (HT), is an autoimmune disease with thyroid goiter, documented by elevated circulating anti-thyroid peroxidase (TPO) antibodies, anti-thyroglobulin (Tg) antibodies, and anti-thyroid-stimulating hormone (TSH) antibodies.

\section{Aim}

Thymus is well-known to be essential for T-cell differentiation and for the establishment of central tolerance. Therefore, an investigation of thymic pathological disorders could be of interest in establishing a possible mechanism for MG associated with anti-AChR antibodies and HT. As such, the aim of this study is to investigate the pathology of thymus in Romanian patients with anti-AChR antibodypositive MG and concomitant HT and to compare our results with the literature.

\section{ㅁ Patients, Materials and Methods}

This is a retrospective case series study reviewing demographic, clinical, imaging, laboratory, thymic pathology, and outcome data obtained from medical records of patients with MG with anti-AChR antibodies and concomitant HT, which were recruited from a single surgical unit of a tertiary referral hospital located in the North-Eastern region of Romania. All the patients were admitted and treated in the Third Clinic of Surgery, St. Spiridon Emergency County Hospital, Iaşi, Romania, over a period of 11 years (from January 1, 2000 to December 31, 2010).

All patients were subjects of a thymectomy that was performed for a suspected thymic lesion.
For all the patients included in the present study, we analyzed the followings: the date of thymectomy, patients' gender and age at the time of thymectomy, values of antiAChR antibodies, electrophysiological findings, clinical severity, which was graded according to the $M G F A$ scale at the last admittance. We also noted: imaging features of the thymus, type of thymic surgery and morphological features of the surgical thymic specimens.

We also considered: the length of time between HT diagnosis and thymectomy, but also the past values of anti-TPO antibodies (normal range: $<35 \mathrm{IU} / \mathrm{mL}$ ); anti$\mathrm{Tg}$ antibodies (normal range: $<35 \mathrm{IU} / \mathrm{mL}$ ), TSH (normal range: $0.4-5.5 \mu \mathrm{IU} / \mathrm{mL}$ ), free thyroxine (fT4) (normal range: $0.9-2.3 \mathrm{ng} / \mathrm{dL}$ ) at the moment of HT diagnosis. We also noted other autoimmune associated diseases that were detected in these patients throughout their life.

Two pathologists reviewed all the histological sections and new immunohistochemical (IHC) stainings were decided to be carried out on the representative paraffin blocks. As such, histological sections with a thickness of $3 \mu \mathrm{m}$ were dried for one hour at $65^{\circ} \mathrm{C}$ before the pretreatment procedure of deparaffinization and rehydration. The epitope was retrieved in citrate buffer, $\mathrm{pH}$ 6.5, or in alkaline buffer (depending on the antibody we used) in water bath at $95^{\circ} \mathrm{C}$ for 30 minutes. Before immunostaining the sections, endogenous peroxidase activity was blocked. We used the following antibodies: anti-cytokeratin (CK) AE1/AE3 (Dako, Denmark), anti-p63 (ImmunoLogic, Netherlands), anticluster of differentiation (CD)5 (Novocastra, UK), antiCD20 (Dako, Denmark), CD23 (Novocastra, UK), antiCD68 (Novocastra, UK), anti-Ki67 (ThermoScientific, USA) and anti-p63 (ImmunoLogic, Netherlands) (Table 1).

After incubation, the reaction was visualized with UltraVision $^{\mathrm{TM}}$ Quanto Detection System Horseradish Peroxidase (HRP), using 3,3'-Diaminobenzidine (DAB) chromogen as a substrate. Sections were counterstained with Mayer's Hematoxylin for nuclear counterstaining. The reaction was considered positive only when a brown cytoplasmic, membranous, or nuclear immunostaining was detected.

The study was managed in full compliance with the ethical principles. Informed consent was obtained from all the patients.

\section{口 Results}

We performed our study on four patients, three females and one male (F:M ratio, 3:1) (Table 2). The mean age of the patients at the time of their thymectomy was 40.25 years, but the female patients were older ( 47.33 years), while the male patient was in his youth (19 years). $75 \%$ of all patients presented moderate or severe $\mathrm{MG}$, and $100 \%$ of them showed anti-AChR antibodies and a decrement greater than $25 \%$ on electromyographic investigations (Table 2).

All patients have been diagnosed in their past medical history with HT by a full thyroid panel (high TSH values, low fT4 values, and anti-TPO antibodies) (Table 3). ATD responded well to the treatment with Euthyrox.

For Case No. 1, HT preceded MG with one year. In Case No. 2 and Case No. 4, the two autoimmune diseases appeared simultaneously. In Case No. 3, MG was diagnosed four years before HT. In Case No. 4, alongside of MG and HT, our patient was also diagnosed with a hemolytic anemia [very low hemoglobin $(\mathrm{Hb})$ count $(4.5 \mathrm{~g} / \mathrm{dL})$, reticulo- 
cytosis, high values for lactate dehydrogenase (LDH) and indirect bilirubin, and positive Coombs test] at the time of his thymectomy (Tables 2 and 3 ).

In our series, we found four MG subtypes: early-onset myasthenia gravis (EOMG), late-onset myasthenia gravis (LOMG), thymoma-associated myasthenia gravis (TAMG), and ocular-associated myasthenia gravis (OAMG), all of them being associated with anti-AChR antibodies, and different thymus pathology, i.e., atrophic thymus with calcification or with cystic dilatations of Hassall's corpuscles, thymic follicular hyperplasia, or B2 invasive thymoma (Table 4).

Table 1 - The antibodies we used for immunohistochemical staining of the analyzed thymic pathologies

\begin{tabular}{|c|c|c|c|c|c|c|c|}
\hline Antibody & Manufacturer & Clone & Antigen retrieval & Class & Dilution & Labeling & $\begin{array}{c}\text { Cellular } \\
\text { localization }\end{array}$ \\
\hline $\begin{array}{l}\text { Anti-CK } \\
\text { AE1/AE3 }\end{array}$ & Dako & AE1/AE3 & Citrate, $\mathrm{pH} 6$ & $\begin{array}{l}\text { Monoclonal mouse anti- } \\
\text { human } \mathrm{CK} \text { AE1/AE3 }\end{array}$ & $1: 50$ & Epithelial cells & Cytoplasmic \\
\hline Anti-CD5 & Novocastra & $4 \mathrm{C} 7$ & Citrate, $\mathrm{pH} 6$ & $\begin{array}{l}\text { Monoclonal mouse } \\
\text { anti-CD5 antibody }\end{array}$ & $1: 100$ & T cells & Membranary \\
\hline Anti-CD20 & Dako & L26 & Citrate, $\mathrm{pH} 6$ & $\begin{array}{l}\text { Monoclonal mouse } \\
\text { anti-human CD20cy }\end{array}$ & $1: 150$ & B cells & Membranary \\
\hline Anti-CD23 & Novocastra & 1B12 & Citrate, $\mathrm{pH} 6$ & $\begin{array}{l}\text { Monoclonal mouse } \\
\text { anti-CD23 antibody }\end{array}$ & $1: 100$ & $\begin{array}{c}\text { Follicular } \\
\text { dendritic cells }\end{array}$ & Membranary \\
\hline Anti-CD68 & Novocastra & $514 \mathrm{H} 12$ & $\mathrm{pH} 9$ & $\begin{array}{l}\text { Monoclonal mouse } \\
\text { anti-CD68 antibody }\end{array}$ & $1: 100$ & Macrophages & $\begin{array}{c}\text { Cytoplasmic and } \\
\text { membranary }\end{array}$ \\
\hline Anti-Ki67 & ThermoScientific & SP6 & Citrate, $\mathrm{pH} 6$ & $\begin{array}{l}\text { Monoclonal rabbit } \\
\text { anti-Ki67antibody }\end{array}$ & $1: 250$ & $\begin{array}{c}\text { Proliferating } \\
\text { cells }\end{array}$ & Nuclear \\
\hline Anti-p63 & ImmunoLogic & $4 \mathrm{~A} 4$ & Citrate, $\mathrm{pH} 6$ & $\begin{array}{l}\text { Monoclonal mouse } \\
\text { anti-human p63 }\end{array}$ & $1: 200$ & Epithelial cells & Nuclear \\
\hline
\end{tabular}

CD: Cluster of differentiation; CK: Cytokeratin.

Table 2 - Clinical characteristics and diagnostic work-up for MG of our patients at the moment of myasthenia diagnosis

\begin{tabular}{ccccccc}
\hline \multirow{2}{*}{$\begin{array}{c}\text { Case } \\
\text { No. }\end{array}$} & $\begin{array}{c}\text { Patient's age at } \\
\text { thymectomy } \\
\text { [years] }\end{array}$ & Gender & & \multicolumn{4}{c}{ MG - history and work-up study } \\
\cline { 3 - 7 } & 54 & $\mathrm{~F}$ & $\begin{array}{c}\text { Length of time between MG } \\
\text { diagnosis and thymectomy }\end{array}$ & $\begin{array}{c}\text { MG } \\
\text { type }\end{array}$ & $\begin{array}{c}\text { Anti-AChR antibody } \\
\text { [nmol/dL] }\end{array}$ & $\begin{array}{c}\text { Electromyographic } \\
\text { decrement }^{*}\end{array}$ \\
\hline 1. & 28 & F & 6 months & IIIA & 6 & $25 \%$ \\
\hline 2. & 60 & F & 8 years & IIIA & 16 & $62 \%$ \\
\hline 3. & 19 & M & 1 year & I & 4 & $32 \%$ \\
\hline 4. & 19 & &
\end{tabular}

AChR: Acetylcholine receptor; F: Female; M: Male; MG: Myasthenia gravis [MG Foundation of America (MGFA) class]. *Normal range: $\leq 0.25$ nmol/dL; \#Normal muscle produces a decrement up to $8 \%$.

Table 3 - History and diagnostic work-up for HT of our patients at the moment of their chronic thyroiditis diagnosis

\begin{tabular}{|c|c|c|c|c|c|c|c|c|}
\hline \multirow{2}{*}{$\begin{array}{l}\text { Case } \\
\text { No. }\end{array}$} & \multirow{2}{*}{$\begin{array}{c}\text { Patient's age at } \\
\text { thymectomy } \\
\text { [years] }\end{array}$} & \multirow{2}{*}{ Gender } & \multicolumn{5}{|c|}{$\begin{array}{l}\text { Chronic autoimmune HT - history and work-up study } \\
\text { at the moment of diagnosis }\end{array}$} & \multirow{2}{*}{$\begin{array}{l}\text { Other autoimmune- } \\
\text { associated disease }\end{array}$} \\
\hline & & & $\begin{array}{l}\text { Length of time between } \mathrm{HT} \\
\text { diagnosis and thymectomy }\end{array}$ & $\begin{array}{l}\text { TPO ab } \\
{[I U / m L]}\end{array}$ & $\begin{array}{c}T g a b \\
{[I U / m L]}\end{array}$ & $\begin{array}{c}T S H \\
{[\mu / U / m L]}\end{array}$ & $\begin{array}{c}f T 4 \\
{[n g / d L]}\end{array}$ & \\
\hline 1. & 54 & $\mathrm{~F}$ & 5 years & 556 & 53 & 2 & 1.2 & - \\
\hline 2. & 28 & $F$ & 6 months & 176.7 & 47 & 6.53 & 1.1 & - \\
\hline 3. & 60 & $\mathrm{~F}$ & 4 years & 184 & 62 & 8.41 & 0.93 & - \\
\hline 4. & 19 & M & 1 year & 63 & 46 & 2.95 & 0.97 & $\begin{array}{l}\text { - Hemolytic anemia: } \\
\text { Hb } \downarrow \text { (4.5 g/dL); } \\
\text { - Reticulocytosis; } \\
\text { - LDH } \uparrow ; \\
\text { - Indirect bilirubin } \uparrow ; ~ \\
\text { - Positive Coombs test. }\end{array}$ \\
\hline
\end{tabular}

F: Female; fT4: Free thyroxine (normal range: 0.9-2.3 ng/dL); Hb: Hemoglobin; HT: Hashimoto's thyroiditis; LDH: Lactate dehydrogenase; M: Male; Tg ab: Anti-thyroglobulin antibodies (normal range: <35 IU/mL); TPO ab: Serum anti-thyroid peroxidase antibodies (normal range: $<35 \mathrm{IU} / \mathrm{mL}$ ); TSH: Thyroid-stimulating hormone (normal range: $0.4-5.5 \mu \mathrm{lU} / \mathrm{mL}$.

Table 4 - Imaging, surgical, pathological and outcome characteristics of our patients at the time of their thymectomy

\begin{tabular}{|c|c|c|c|c|c|c|c|}
\hline $\begin{array}{l}\text { Case } \\
\text { No. }\end{array}$ & $\begin{array}{c}\text { Age } \\
\text { [years] }\end{array}$ & Gender & Thoracic CT scan & Surgery & Pathological report & $\begin{array}{l}\text { Type of } \\
\text { MG }\end{array}$ & Outcome \\
\hline 1. & 54 & $\mathrm{~F}$ & $\begin{array}{c}\text { Enlarged antero-superior } \\
\text { mediastinum with a heterogeneous } \\
\text { thymic tissue }\end{array}$ & $\mathrm{T}$ & $\begin{array}{c}\text { Atrophic thymus with } \\
\text { calcification of Hassall's } \\
\text { corpuscles (Figure 1, a and b) }\end{array}$ & LOMG & $\begin{array}{l}\text { Death - MSOF } \\
\text { at } 60 \text { days }\end{array}$ \\
\hline 2. & 28 & $F$ & Nodular thymus (Figure 2, a and b) & $\mathrm{T}$ & $\begin{array}{l}\text { Thymic follicular hyperplasia } \\
\text { (Figure 3; Figure 4, a-f) }\end{array}$ & EOMG & $\begin{array}{c}\text { Complete } \\
\text { remission of MG }\end{array}$ \\
\hline 3. & 60 & $\mathrm{~F}$ & $\begin{array}{c}\text { Mediastinal mass invasive into the } \\
\text { left mediastinal pleura - suggestive } \\
\text { for thymoma (Figure 5a) }\end{array}$ & $\mathrm{T}$ & $\begin{array}{l}\text { B2 invasive thymoma } \\
\text { (Figure } 5 b ; \text { Figure } 6, a-h \text { ) }\end{array}$ & TAMG & $\begin{array}{c}\text { Complete } \\
\text { remission of MG }\end{array}$ \\
\hline 4. & 19 & M & $\begin{array}{l}\text { Mediastinal mass suggestive for } \\
\text { thymoma (Figure } 7 \mathrm{~b})\end{array}$ & $\mathrm{T}$ & $\begin{array}{l}\text { Atrophic thymus with cystic } \\
\text { dilatations of Hassall's } \\
\text { corpuscles (Figure } 8, a-d)\end{array}$ & OAMG & $\begin{array}{l}\text { Complete } \\
\text { remission of MG }\end{array}$ \\
\hline
\end{tabular}

CT: Computed tomography; EOMG: Early-onset myasthenia gravis; F: Female; LOMG: Late-onset myasthenia gravis; M: Male; MG: Myasthenia gravis; MSOF: Multisystem organ failure; OAMG: Ocular-associated myasthenia gravis; T: Thymectomy; TAMG: Thymoma-associated myasthenia gravis. 

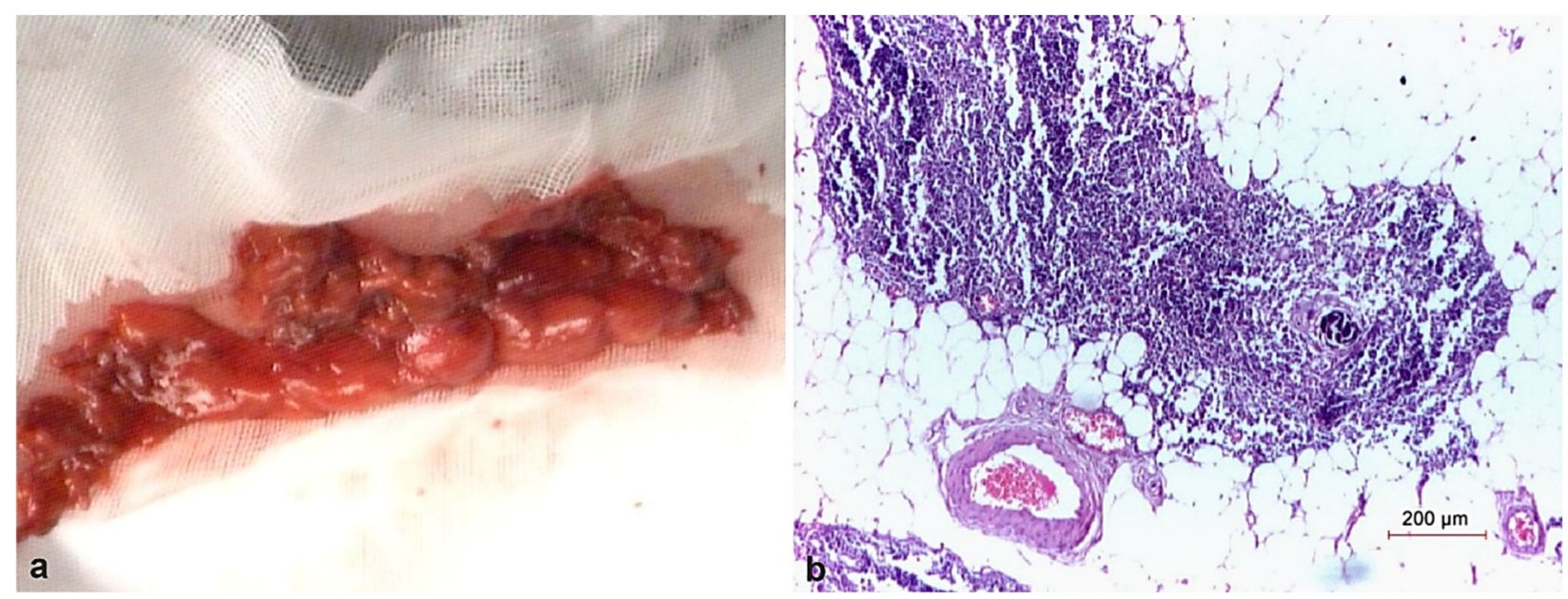

Figure 1 - Case No. 1. F, 54-year-old. (a) Surgical specimen-nodular aspect of the thymus gland; (b) Morphological features - atrophy of the thymus with calcification of a Hassall's corpuscle (HE staining, ×40). F: Female; HE: Hematoxylin-Eosin.
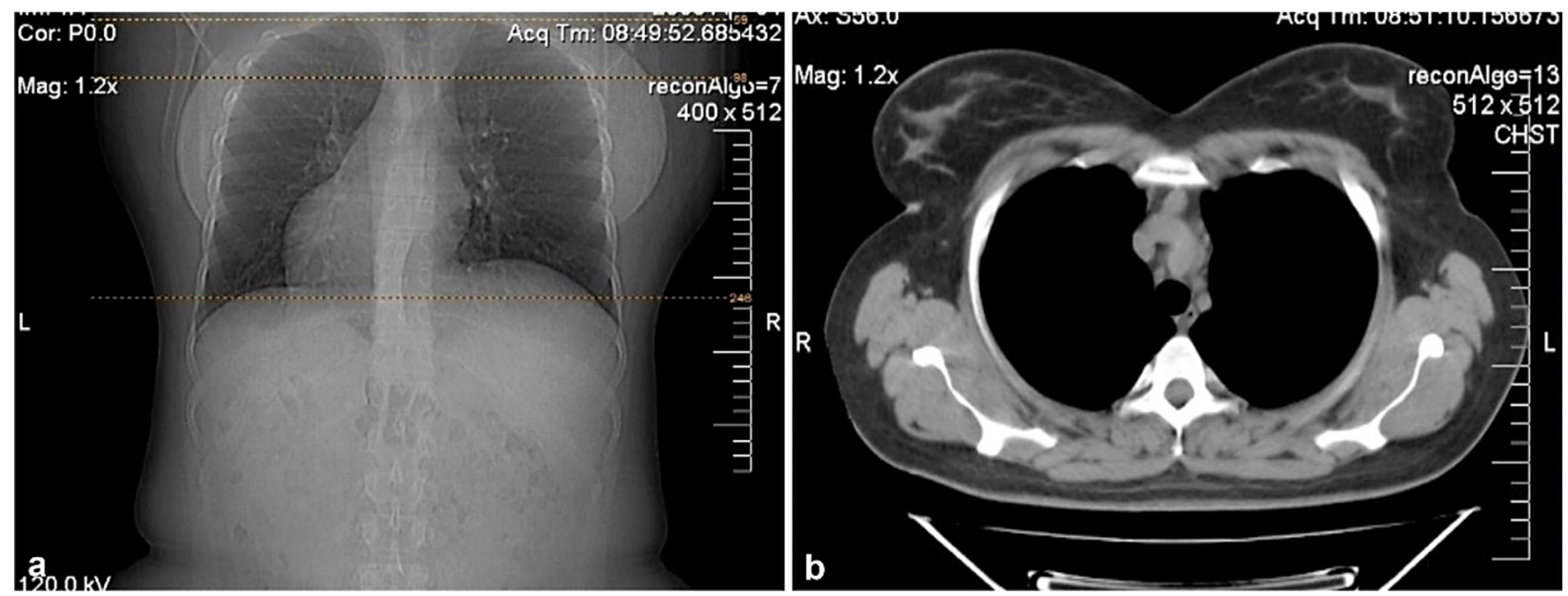

Figure 2 - Case No. 2. F, 28-year-old. Thymic follicular hyperplasia, thoracic CT scan: (a) Enlarged heterogeneous thymus (coronal plane); (b) Some nodules may be distinguished from adipose tissue (axial plane). CT: Computed tomography; F: Female.

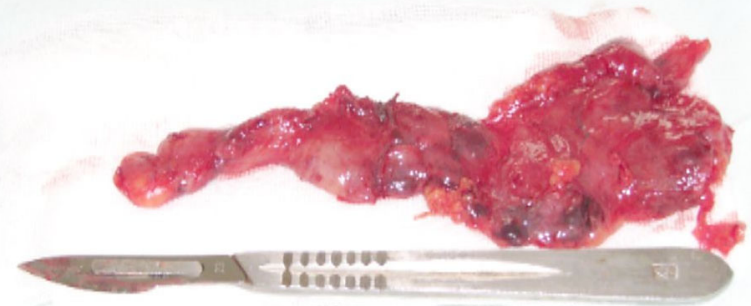

Figure 3 - Case No. 2. F, 28-year-old. The resected thymectomy specimen was $9.5 \times 5.5 \times 2.5 \mathrm{~cm}$ in size and weighed 65 g. F: Female. 


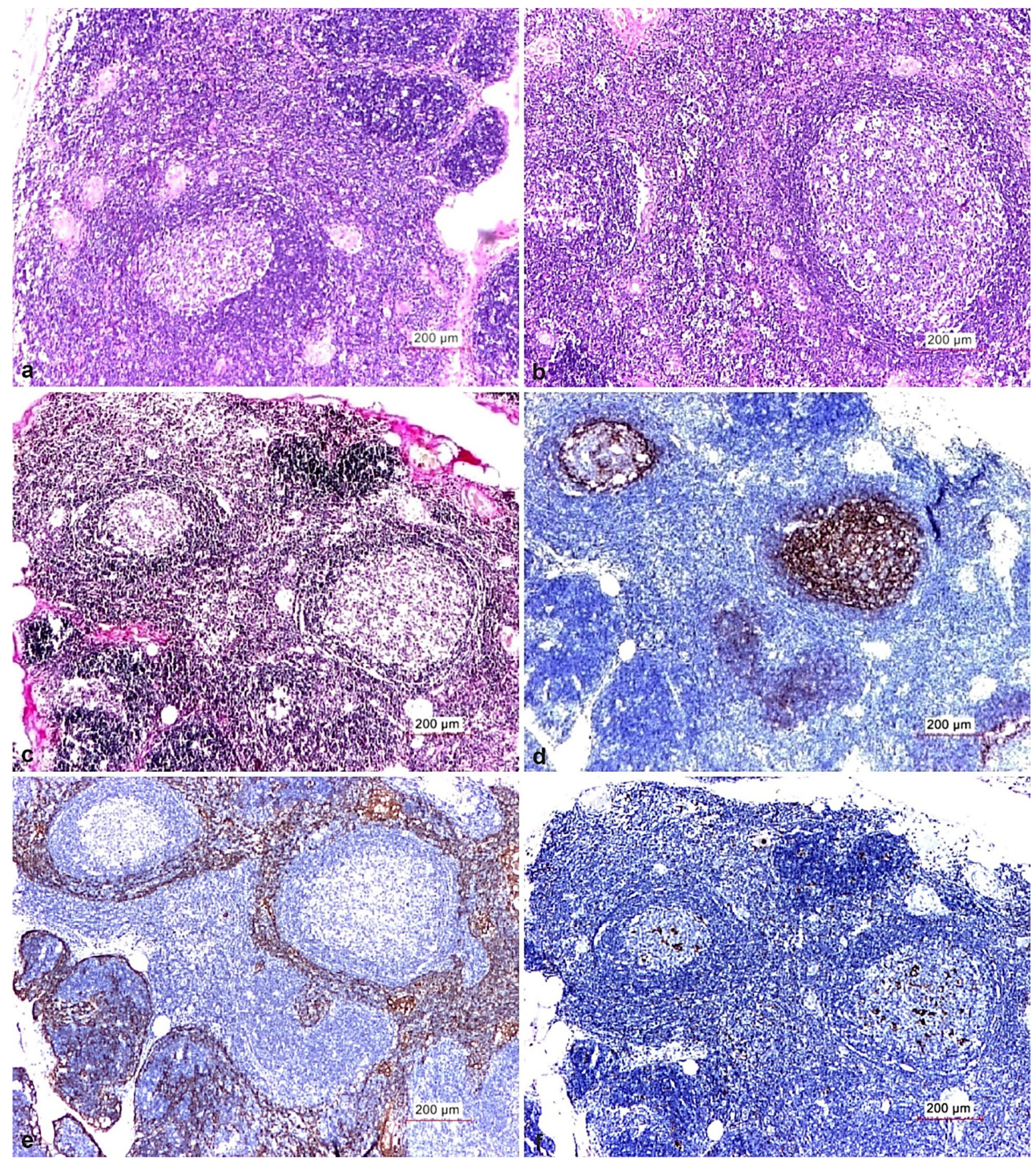

Figure 4 - Case No. 2. F, 28-year-old. Thymic follicular hyperplasia. Morphological and immunohistochemical features: (a) Thymic tissue with increased density of lymphoid follicles with hyperplastic germinal centers and occasional Hassall's corpuscles; (b) The same image, but at higher magnification, revealed active germinal center; (c) Many lymphoid follicles, small and big, with prominent germinal centers expanded thymic medulla; (d) Lymphoid follicles from thymic medullary area showed CD23 immunopositivity in the follicular dendritic cell network (brown staining); (e) Immunopositivity for CK AE1/AE3 of the thymic epithelial cells revealed the fact that hyperplastic lymphoid follicles disrupted the normally epithelial network, but at the same time a thymic epithelial hyperplasia could be seen around each reactive follicle; (f) CD68 immunopositivity identified few macrophages in cortical and medullary regions. HE staining: (a) $\times 40 ;(b) \times 100$. Van Gieson staining: (c) $\times 40$. Anti-CD23 antibody immunomarking: (d) $\times 40$. Anti-CK AE1/AE3 antibody immunomarking: (e) $\times 40$. Anti-CD68 antibody immunomarking: $(f) \times 40$. CD: Cluster of differentiation; CK: Cytokeratin; HE: Hematoxylin-Eosin; F: Female. 

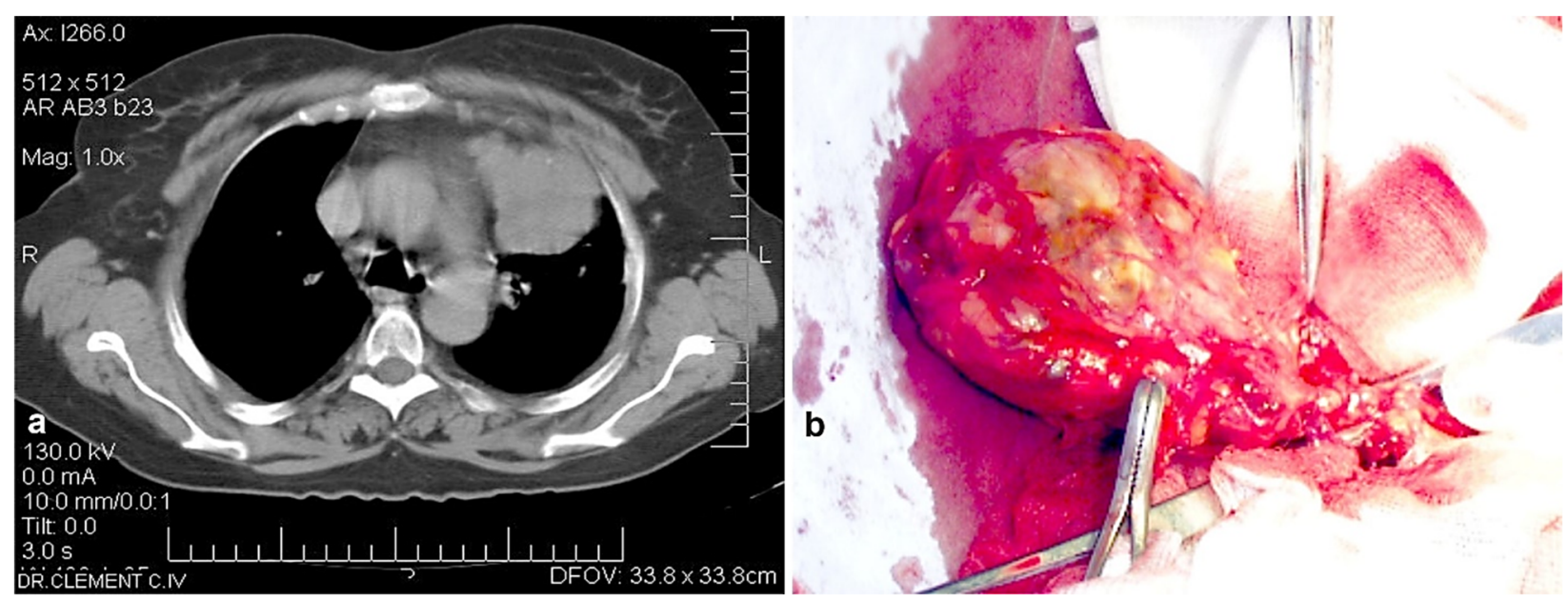

Figure 5 - Case No. 3. F, 60-year-old. B2 thymoma: (a) Thoracic CT scan at the level of the thymus showing a lobular anterior mediastinal mass, infiltrating the adjacent pleura (axial plane); (b) Gross features of the surgical specimenpink-tan, solid tumor showing multiple nodules and having the greatest diameter of $6.1 \times 3.5 \mathrm{~cm}$. CT: Computed tomography; F: Female.

Thoracic CT revealed a heterogeneous mediastinal mass and established the correct diagnosis only in $25 \%$ of cases, i.e., in the case of invasive thymoma (Table 4; Figure 2, a and b; Figure 5a; Figure 7, a and b). The gross features of thymic surgical specimens also revealed heterogeneous morphological appearances: atrophic thymus in two cases (Figure 1a), a tumor mass in one case (Figure 5b) and a nodular thymus in another case (Figure 3).

Furthermore, the pathological exam revealed a heterogeneous pattern of the thymic lesions, ranging from atrophy to thymic follicular hyperplasia and invasive thymoma (Table 4; Figure 1b; Figure 4, a-f; Figure 6, a-h). Atrophic thymus also expressed different morphological changes of Hassall's corpuscles: calcification (Figure 1b) or cystic dilatations (Figure 8, a-d). Thymic lympho-follicular hyperplasia (TLFH) expressed an increased density of lymphoid follicles with activated germinal centers and different dimensions, which expanded thymic medulla and disrupted the normally epithelial network as could be seen with CK AE1/AE3 immunostaining. In the follicular dendritic cell network, there were cells showing CD23 immunopositivity (Figure 4, a-f).

In B2 thymoma, tumoral epithelial cells, setting in a background of abundant lymphocytes, expressed CK19 immunoreactivity, very high values $(80 \%)$ for Ki67 labeling index, but most of the nuclear staining represented Tlymphocytes, and strong and diffuse immunopositivity for p63. Also, IHC staining revealed the characteristics of the intratumoral population of lymphocytes: CD20 immunopositivity of B-lymphocytes infiltrate and strong CD5 immunopositivity of T-lymphocytes infiltrate (Figure 6, $\mathrm{a}-\mathrm{h})$.

Regarding the outcome of our patients, we found out a complete remission of MG in $75 \%$ of our patients undergoing a total thymectomy, but one patient $(25 \%$ of all cases) died at 60 days after surgical intervention due to a multisystem organ failure (MSOF).

\section{Discussions}

MG can be associated in $15 \%$ of cases with another autoimmune disease, i.e., thyroid disease, rheumatoid arthritis, and systemic lupus erythematosus, and this association could signify a possible common basis for all these diseases, as well as their impact on the intensity and treatment of MG [10].

Patients diagnosed with MG can associate all kinds of morphological and functional thyroid disorders, including ATDs [11], but Graves' disease and HT are more prevalent in patients with MG than in the general population [12].

The association between MG and HT has been reported since the 1960s, but it is still rare, as the literature mentions a percentage ranging between $1.1 \%$ and $9 \%[13,14]$.

The literature also shows some case studies of MG associated with HT that have been published especially during the second half of the 20th century [15-17]. It was only in 1972, while presenting a 64-year-old Chinese woman with MG and HT, Cheah \& Tan hypothesized that MG could be an autoimmune disorder [18]. However, at the beginning of the 21 st century, especially in the last five years, however, due to the emergence of new methods of investigation, some series of cases have been published [14].

ATDs and MG present some common elements, as both pathologies appear because of a deficient immune response against self-structures. From a morphological point of view, HT contains a rich lymphocytic infiltrate predominantly disposed in follicles with germinal center formation. In this case, lymphocytes are predominantly T-cells subtype [19].

Chronic autoimmune thyroiditis should be treated, otherwise a hypothyroidism could develop, and severe complications could be added to those expressed by the associated MG, such as extensive intracerebral calcification leading to death [20].

However, ATDs often accompany MG and may influence its evolution. These two diseases can occur at the same time or one of them can precede the other [21].

Moreover, some authors claim that ATD, especially HT, has a high risk of being subsequent to MG [22]. In our series, in two cases, these two autoimmune diseases appeared simultaneously, in another case MG preceded HT by four years, and in the fourth case HT preceded MG by one year. 

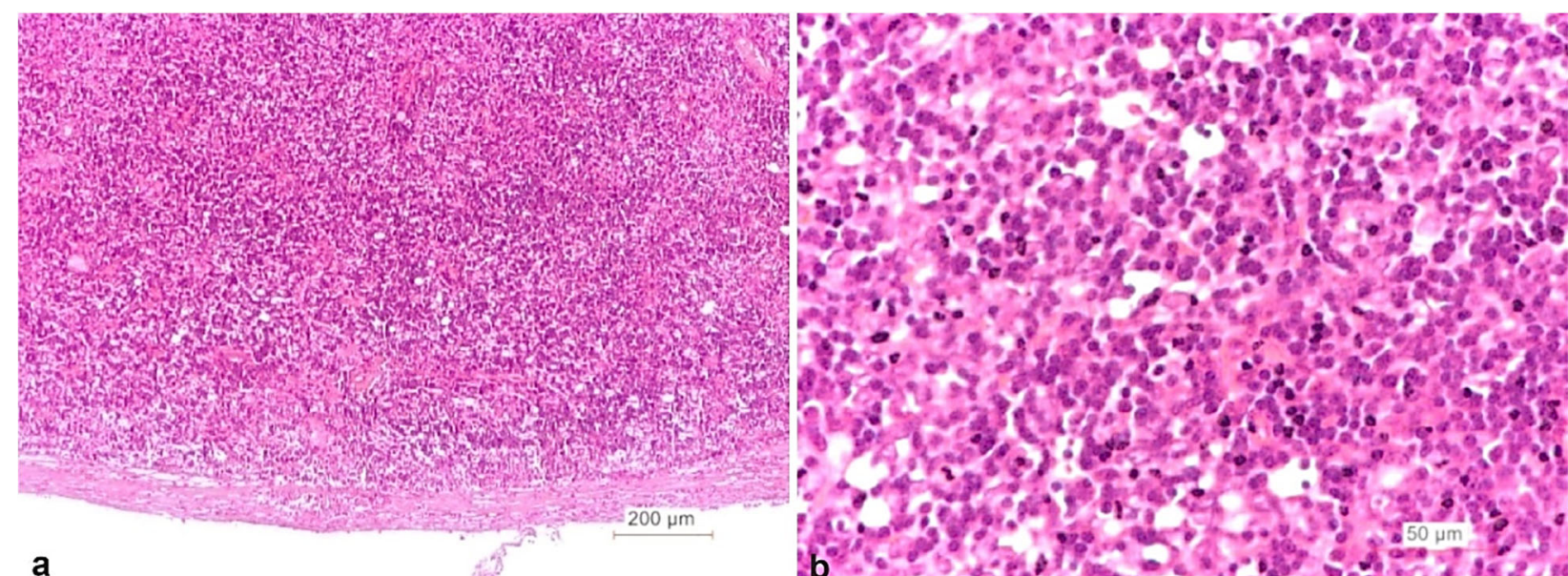

a

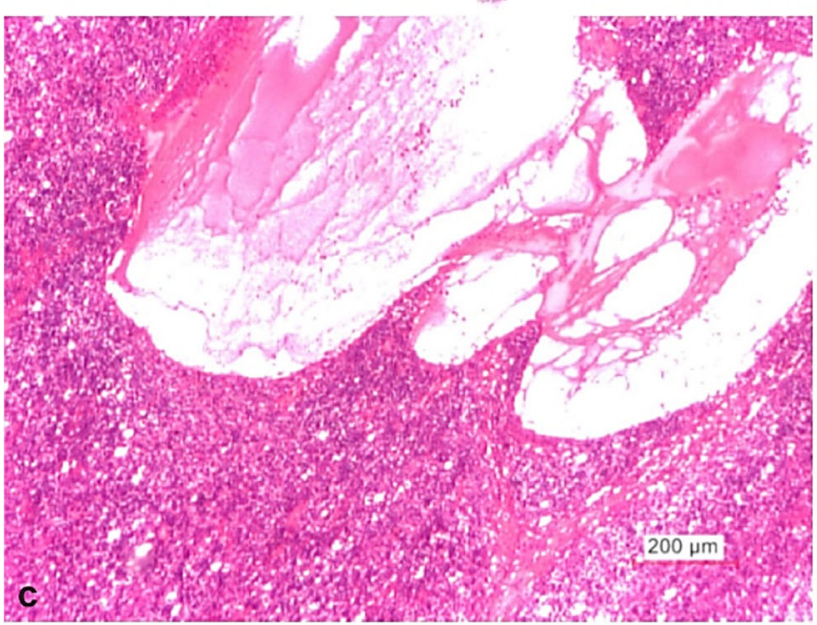

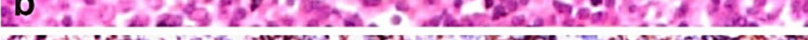

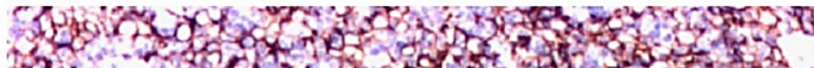

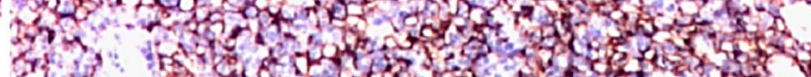

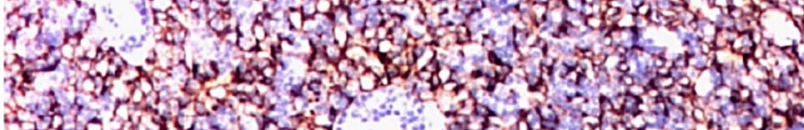

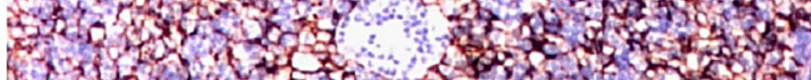

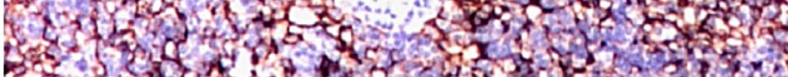

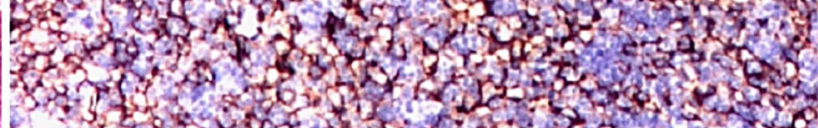

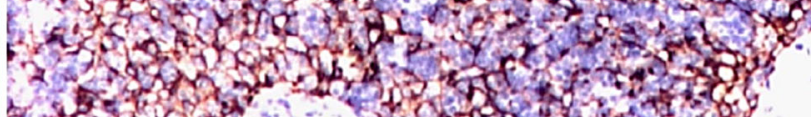

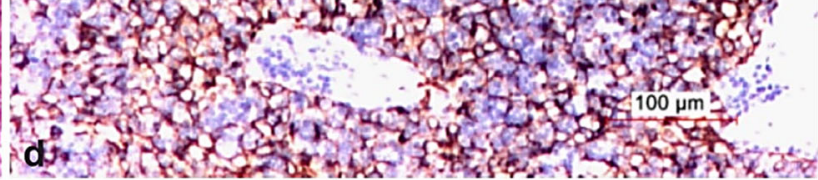

6.

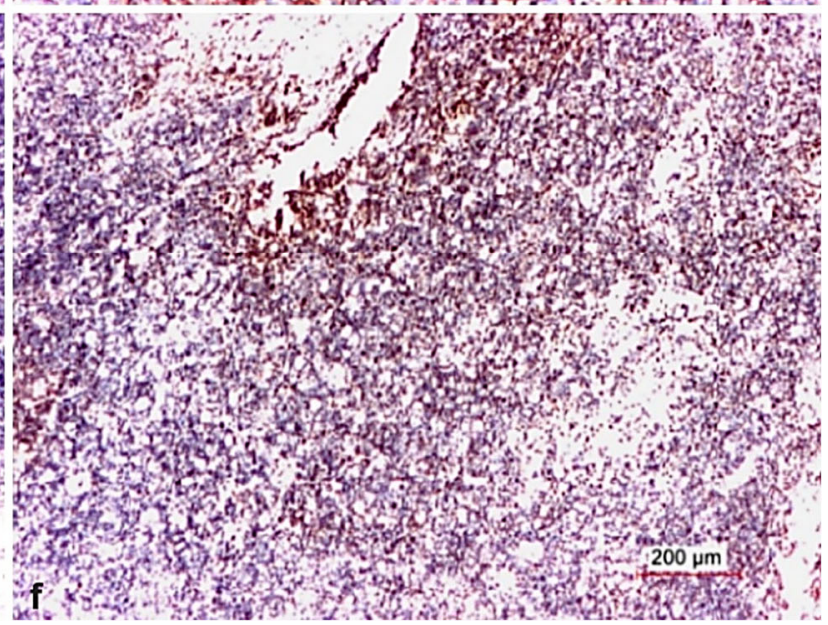

Figure 6-Case No. 3. F, 60-year-old. B2 thymoma. Morphological and immunohistochemical features: (a) Tumor made up of two distinct cellular populations - clusters of large polygonal neoplastic epithelial cells setting on a background of numerous lymphocytes; the tumor presented a fibrous capsule infiltrated by tumoral cells; (b) Admixture of clusters of polygonal epithelial cells and lymphoid cells; the epithelial cells were larger than the lymphoid cells and presented hypochromatic nuclei with small nucleoli; the lymphocytes were uniform, with scant cytoplasm, round nuclei, and inconspicuous nucleoli; (c) Within the tumor there were some perivascular spaces centered by a venule surrounded by a clear space containing proteinaceous fluid; (d) CK19 immunoreactivity of neoplastic epithelial cells setting in a background of abundant lymphocytes; (e) CD20 immunostaining was positive in B-lymphocytes infiltrate and negative in the epithelial neoplastic component (immunoperoxidase with Hematoxylin counterstaining); (f) Strong CD5 immunopositivity of T-lymphocytes infiltrate, but negative in the epithelial neoplastic component (immunoperoxidase with Hematoxylin counterstaining). HE staining: (a and c) $\times 40$; (b) $\times 100$. Anti-CK19 antibody immunomarking: (d) $\times 100$. AntiCD20 antibody immunomarking: $(e) \times 400$. Anti-CD5 antibody immunomarking: $(f) \times 400$. CD: Cluster of differentiation; CK: Cytokeratin; HE: Hematoxylin-Eosin; F: Female. 


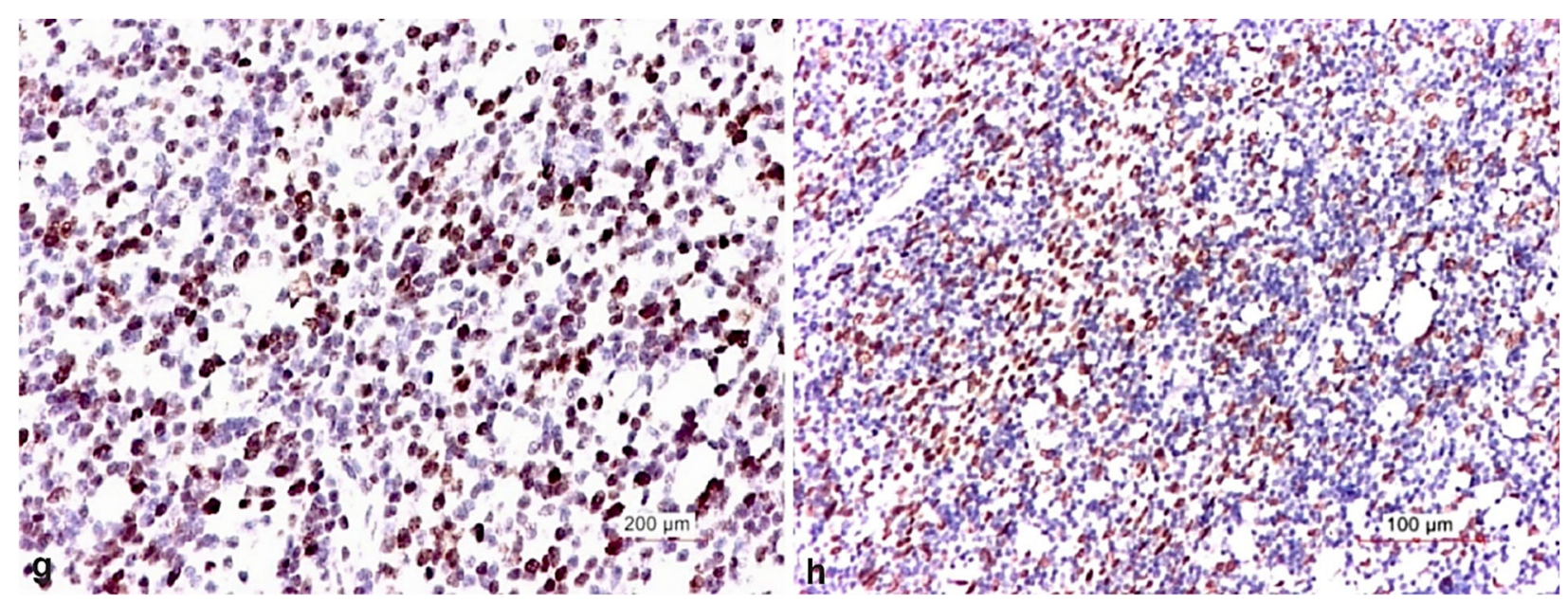

Figure 6 (continued) - Case No. 3. F, 60-year-old. B2 thymoma. Morphological and immunohistochemical features: (g) Ki67 labeling index showed high values (>80\%), but most of the nuclear staining represented T-lymphocytes; however, some larger epithelial cells were also immunopositive for Ki67; (h) Strong and diffuse immunopositivity for p63 in the tumoral epithelial cells. Anti-Ki67 antibody immunomarking: $(g) \times 200$. Anti-p63 antibody immunomarking: $(h) \times 100$. F: Female.
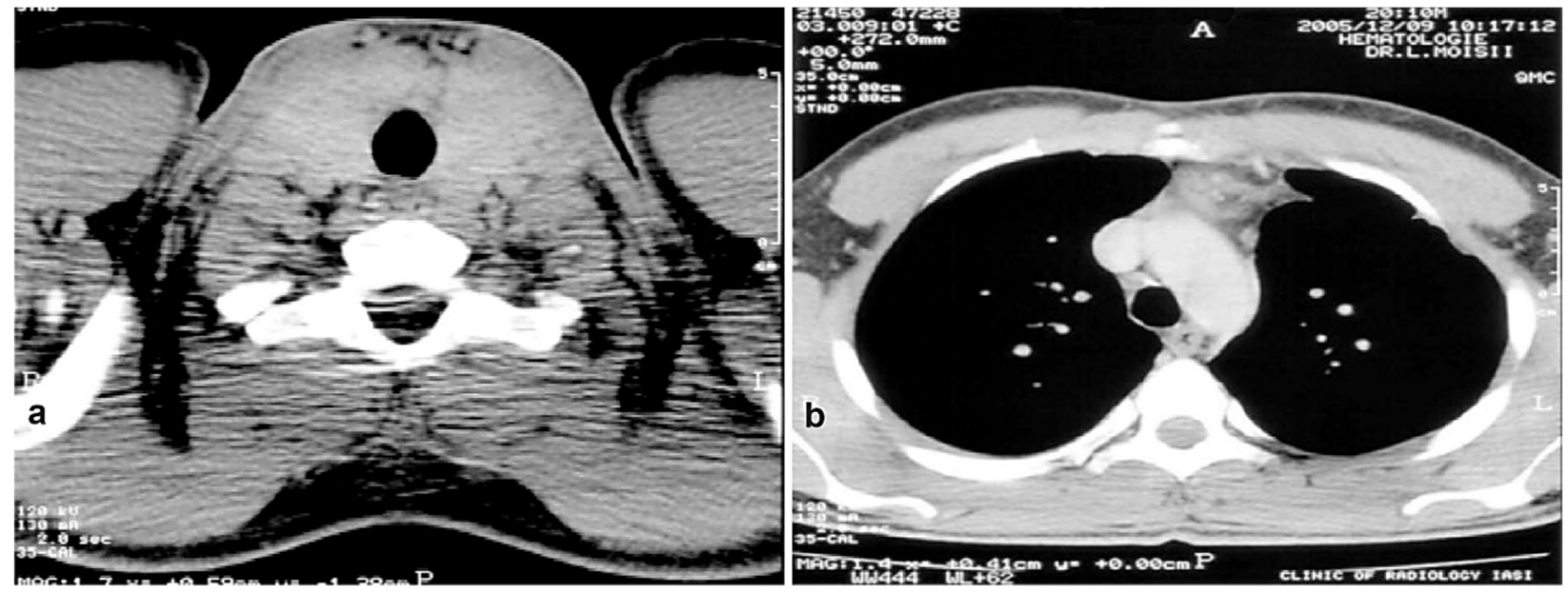

Figure 7 - Case No. 4. M, 19-year-old. Thymic atrophy with cystic degeneration of Hassall's corpuscles: (a) CT scan of the neck demonstrated a heterogeneously enlarged thyroid gland (axial view); (b) Thoracic CT scan revealed a nodular mediastinal mass suggestive for thymoma (axial view). CT: Computed tomography; M: Male.

Patients with MG could also develop other autoimmune diseases than HT. In our series, the youngest patient was also diagnosed with hemolytic anemia at the time of his thymectomy. Arellano et al. (2017) reported another, even rarer association, presenting the case of a 69-year-old patient with idiopathic pulmonary fibrosis associated to his $\mathrm{HT}$ and MG [23].

Kubiszewska et al. (2016) investigated 343 consecutive patients with MG [14]. These researchers found that only $9 \%$ of their cases presented $\mathrm{HT}$ and MG, and most of them were women $(67.7 \%)$, their mean age at onset of MG being 40.4 years. These authors identified only two subtypes of MG (EOMG and LOMG). Their results are similar to ours, especially those data regarding the age and gender of the patients, but in our study, based on clinical and paraclinical features, we identified all four forms of MG expressing anti-AChR antibodies: EOMG, LOMG, TAMG, and OAMG, as they were reported by Koneczny \& Herbst (2019) [5].

Prior to the first surgery for thymus removal in patients with MG, which was performed in 1941 [24], the idea that these patients had structural abnormalities of the thymus appeared based on the histopathological (HP) aspects identified on the autopsy specimens. Since then, microscopic analysis identified the presence of benign tumors, hyperplasia, or the persistence of an atrophic thymus in patients who have died in hospitals due to MG. As far as we know, there are two articles reporting the morphological aspects of the thymic surgical specimens in correlation with the type of MG [5, 25], but our study is the only one presenting HP and IHC images of thymic pathology in patients with MG and concomitant HT. An interesting fact is that we found different thymus pathologies for each subtype of MG.

Some other Romanian authors reported the HP and IHC features of thymoma in patients with MG. Cornea et al. (2009) reported a case with nodular hyperplasia of the thymic epithelium (also called microscopic thymoma), diagnosed in a patient with eye-related symptoms of MG that aggravated in two years of evolution [26]. Cornea et al. (2012) also reported another case of a B1 thymoma in a MG patient and concluded that among IHC markers, only p53 can be used to predict a more aggressive evolution [27]. 


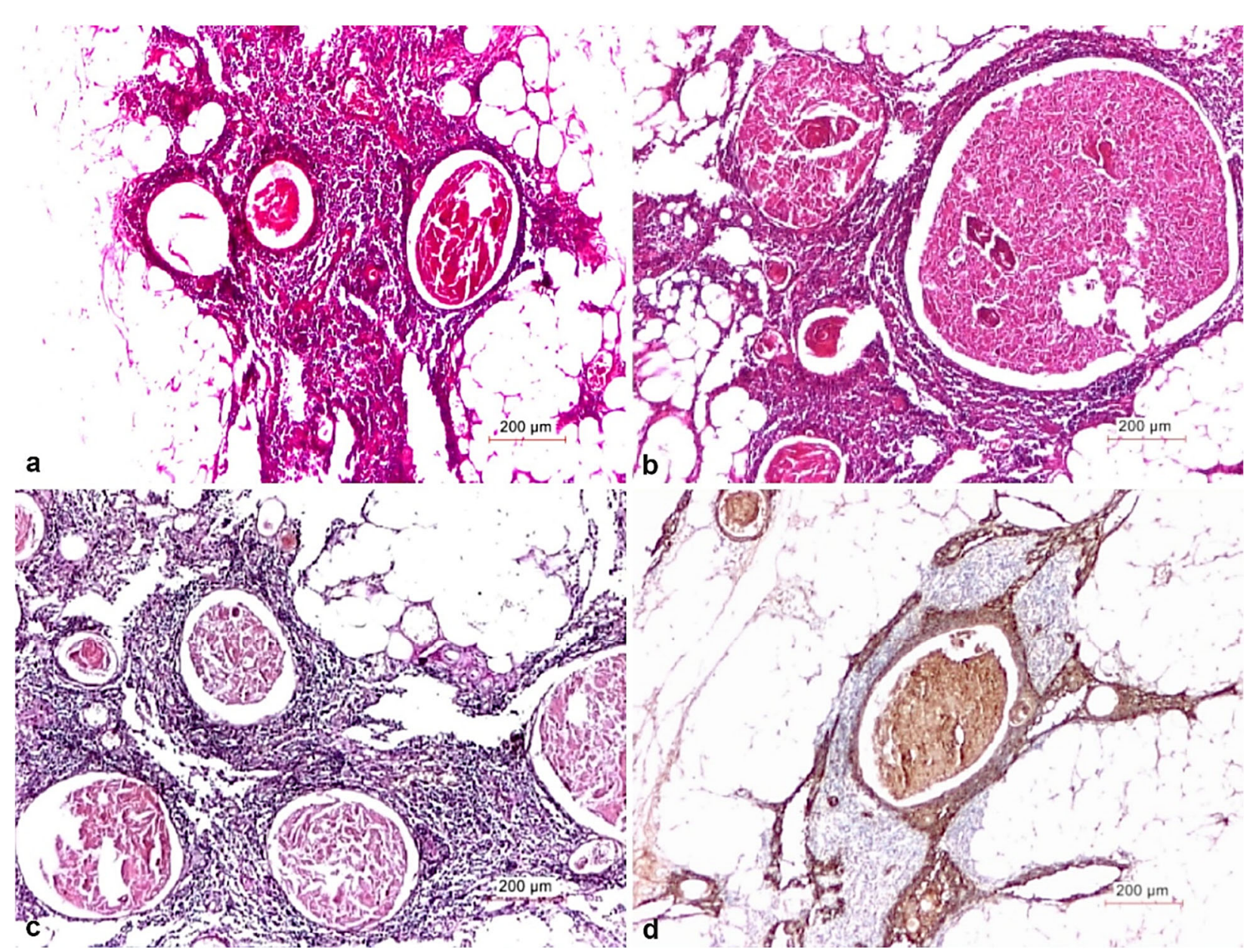

Figure 8 - Case No. 4. M, 19-year-old. Thymic atrophy with cystic degeneration of Hassall's corpuscles. Morphological and immunohistochemical features: (a) Extensive reduction in the thymic cortex with many cystic structures, filled with homogeneous eosinophilic material; (b) Huge cystic dilatation filled up with cellular detritus; (c) Thymic medulla with extremely large cystic dilatation filled with heterogeneous amorphous material; (d) Strong immunopositivity for CK AE1/AE3 revealed the thymic epithelial cells lining inner surface of the cyst and confirmed the cystic transformation of Hassall's corpuscles. HE staining: (a) $\times 40$; (b) $\times 100$. Van Gieson staining: (c) $\times 40$. Anti-CK AE1/AE3 antibody immunomarking: (d) $\times 40$. CK: Cytokeratin; HE: Hematoxylin-Eosin; M: Male.

Our case with HT, MG and invasive B2 thymoma expressed high Ki67 labeling index and strong p63 immunopositivity. These two markers could be the proof for a poor prognosis expressed as tumor recurrence, but if we followed the case her outcome was good.

Even though we investigated only a few cases, we found out that LOMG and OAMG were associated with an atrophic thymus, but with specific features in each case (calcification of Hassall's corpuscles in LOMG, and cystic dilatations of Hassall's corpuscles in OAMG). On the other hand, EOMG exhibited TLFH, with thymic epithelial hyperplasia, and TAMG expressed an invasive thymoma.

The literature highlights the fact that the thymus plays an important role in the pathogenesis of MG with antibodies against the AChR of skeletal muscles. These antibodies are produced in B-cells, but their production depends on T-cells. Potentially specific T-cells for AChR are probably generated in the thymus by a non-tolerogenic thymopoiesis due to an aberrant function of thymic epithelial cells. However, the generation of these T-cells specific for AChR is not the cause of MG, as these cells are also found in healthy people. It seems that MG is triggered by the activation of these potentially specific AChR-specific Tcells. Intra-thymic activation of AChR-specific T-cells is probably limited to certain types of MG patients: those with EOMG in whom the thymus presents TLFH and some patients in whom MG is associated with a thymoma. Most thymomas and atrophic thymuses of the patients with LOMG do not present this T-cell activation process [25]. Since we have identified particular morphological changes in the atrophic thymus of MG patients, we suggest that the constituent cells of these histological structures could also play a role in the pathogenesis of MG, at least in MG with anti-AChR antibodies and concomitant HT.

Some other authors reported that approximately $95 \%$ of patients with MG have thymic abnormalities; up to $65 \%$ of patients have thymic hyperplasia, up to $21 \%$ are diagnosed with thymomas, and in $9 \%$ of cases thymus is normal or regressive, i.e., atrophic and replaced with fat tissue, but in $5 \%$ of cases a persistent thymus could be found [10]. On the contrary, we found $50 \%$ of our patients with atrophic thymus, $25 \%$ of them with thymoma, and $25 \%$ with TLFH, yet our series includes but a few cases.

Nikolic et al. (2013) reported that patients identified with anti-AChR antibodies are more often diagnosed with TLFH or thymoma, while in patients expressing anti-MuSK antibodies an atrophic thymus is most often identified by the pathologists [28]. In contrast with this study, in 
our patients with MG and anti-AChR antibodies and concomitant HT, we identified atrophic thymus more frequently $(50 \%)$, but with particular morphological expression of the Hassall's corpuscles. Some researchers indicate that Hassall's corpuscles differentiate from medullary thymic epithelial cells after they lose autoimmune regulator expression [29].

It could then be extrapolated that not only thymocytes, which interact with thymic epithelial cells [30] can have a role in MG pathogenesis, but also the cells of Hassall's corpuscles could play a role in this process, especially since their function is to train thymocyte subsets to transform into $\mathrm{CD} 4+\mathrm{CD} 25+$ regulatory thymic $\mathrm{T}$-cells, which modulate the immune response and have implications in some autoimmune diseases [31].

Recently, Mikušová et al. (2017) examined 95 human thymic tissue samples to identify the structure and role of Hassall's corpuscles. The authors reported that most of Hassall's corpuscles are heterocellular and consist of thymic epithelial cells, macrophages, interdigitating dendritic cells, myoid cells, and, occasionally, mast cells and lymphocytes. Regarding the potential functions of Hassall's corpuscles, the authors found out that these structures contained high concentrations of B-lymphocytes and B-cell lymphoma 2 (BCL2)-positive lymphocytes, suggesting a role in the regulation of lymphopoiesis [32].

Brinkane et al. (2003) recommend chest X-ray and thoracic CT scan in patients with autoimmune thyroiditis to search for a thymic mass. On the other hand, these authors suggest imaging and laboratory investigations for autoimmune thyroiditis in patients with a thymic mass identified on CT or magnetic resonance imaging (MRI) scans [33]. However, in our series, HT was identified based on clinical manifestation (hypothyroidism) and also on a full thyroid panel, but the diagnosis was finalized concomitantly, before or after the diagnostic of a MG.

Although both MG and HT are autoimmune diseases, their treatment is different. In the case of HT, the treatment aims to regulate the level of thyroid hormones and therefore the patients receive a substitution treatment (Euthyrox given orally throughout their life), to which our patients have responded well. Also, thyroid dysfunction may increase the risk of hypertension. As such, hypertension should be treated, with special awareness that a treatment resistance could occur. In this case, the clinician should search for other causes (atherosclerotic renovascular changes, or systemic amyloidosis) [34, 35].

In cases with $\mathrm{MG}$, drug therapy consists in medications that increase neuromuscular transmission (anticholinesterase agents) and immunomodulating treatments, i.e., glucocorticoids, plasmapheresis, immunoglobulins, and monoclonal antibodies [3].

In the unfavorable evolution of the two diseases, the surgical treatment is of choice. In MG, surgical treatment is done by simple or extended thymectomy [36] and its effect is an improvement of clinical outcome. In HT, thyroid ablation is recommended when a defined thyroid nodule is present. However, it is interesting to note that in both cases the excised organ revealed germinal centers with B-lymphocytes participating in the pathogenic response [37].

After the first thymectomy in 1941, it was subsequently found that surgery has greater benefits in patients with non-thymomatous $\mathrm{MG}$, with remission rate higher than those with non-surgical treatment [3]. Except for one case who died 60 days after surgery due to a multiple organ insufficiency, all other patients from our series showed complete remission of $\mathrm{MG}$ after total thymectomy, emphasizing once again the importance of surgery in patients with MG.

\section{ㅁ Conclusions}

Even though our series has limitations due to its small number of patients, this study is a unique report of HP and IHC features of thymic lesions identified in patients with anti-AChR antibodies-positive MG and concomitant HT. In our series, the two diseases occurred simultaneously, or one of them was diagnosed before the other, raising some new questions regarding the immune mechanism of these two autoimmune diseases. Due to the great variety of thymic morphological changes we found in this study, we can hypothesize that thymus is involved in the pathogenic mechanism of anti-AChR antibodies-positive MG and concomitant HT.

\section{Conflict of interests}

The authors declare that they have no conflict of interests.

\section{References}

[1] Meriggioli MN, Sanders DB. Muscle autoantibodies in myasthenia gravis: beyond diagnosis? Expert Rev Clin Immunol, 2012, 8(5):427-438. https://doi.org/10.1586/eci.12.34 PMID: 22882218 PMCID: PMC3505488

[2] ${ }_{* * *}$. Prevalence and incidence of rare diseases: Bibliographic data. Prevalence, incidence or number of published cases listed by diseases (in alphabetical order). Orphanet Report Series, 2019, Number 1, accessed: October 2019. https:// www.orpha.net/orphacom/cahiers/docs/GB/Prevalence_of_ rare diseases by alphabetical list.pdf

[3] Cataneo AJM, Felisberto G Jr, Cataneo DC. Thymectomy in nonthymomatous myasthenia gravis - systematic review and meta-analysis. Orphanet J Rare Dis, 2018, 13(1):99. https://doi.org/10.1186/s13023-018-0837-z PMID: 29940999 PMCID: PMC6020196

[4] Jaretzki A 3rd, Barohn RJ, Ernstoff RM, Kaminski HJ, Keesey JC, Penn AS, Sanders DB. Myasthenia gravis: recommendations for clinical research standards. Task Force of the Medical Scientific Advisory Board of the Myasthenia Gravis Foundation of America. Neurology, 2000, 55(1):16-23. https://doi.org/10. 1212/wnl.55.1.16 PMID: 10891897

[5] Koneczny I, Herbst R. Myasthenia gravis: pathogenic effects of autoantibodies on neuromuscular architecture. Cells, 2019, 8(7):671. https://doi.org/10.3390/cells8070671 PMID: 31269763 PMCID: PMC6678492

[6] Nacu A, Andersen JB, Lisnic V, Owe JF, Gilhus NE. Complicating autoimmune diseases in myasthenia gravis: a review. Autoimmunity, 2015, 48(6):362-368. https://doi.org/10.3109/089 16934.2015.1030614 PMID: 25915571 PMCID: PMC4616023

[7] Tuncer Elmaci N, Ratip S, Ince-Günal D, Tanridağ T. Myasthenia gravis with thymoma and autoimmune haemolytic anaemia. A case report. Neurol Sci, 2003, 24(1):34-36. https://doi.org/ 10.1007/s100720300019 PMID: 12754655

[8] Nagarajan M, Maasila AT, Dhanapriya J, Dineshkumar T, Sakthirajan R, Rajasekar D, Balasubramaniyan T, Gopalakrishnan N. Systemic lupus erythematosus and myasthenia gravis: a rare association. Indian J Nephrol, 2019, 29(1):6264. https://doi.org/10.4103/ijn.IJN_12_18 PMID: 30814797 PMCID: PMC6375012

[9] Chai JY, Jeon CH, Cha HS, Kim BJ, Koh EM. 4 cases of myasthenia gravis in patients with rheumatoid arthritis. Korean J Med, 2006, 71(3):1147-1152. https://www.ekjm.org/journal/ view.php?number=17121

[10] Tanovska N, Novotni G, Sazdova-Burneska S, Kuzmanovski I, Boshkovski B, Kondov G, Jovanovski-Srceva M, Kokareva A, 
Isjanovska R. Myasthenia gravis and associated diseases. Open Access Maced J Med Sci, 2018, 6(3):472-478. https:// doi.org/10.3889/oamjms.2018.110 PMID: 29610603 PMCID: PMC5874368

[11] Lin YP, Iqbal U, Nguyen PA, Islam MM, Atique S, Jian WS, Li YC (Jack), Huang CL, Hsu CH. The concomitant association of thyroid disorders and myasthenia gravis. Transl Neurosci, 2017, 8:27-30. https://doi.org/10.1515/tnsci-2017-0006 PMID: 28729915 PMCID: PMC5443889

[12] Kanazawa M, Shimohata T, Tanaka K, Nishizawa M. Clinical features of patients with myasthenia gravis associated with autoimmune diseases. Eur J Neurol, 2007, 14(12):14031404. https://doi.org/10.1111/j.1468-1331.2007.01978.x PMID: 17941854

[13] Chen YL, Yeh JH, Chiu HC. Clinical features of myasthenia gravis patients with autoimmune thyroid disease in Taiwan. Acta Neurol Scand, 2013, 127(3):170-174. https://doi.org/10. 1111/j.1600-0404.2012.01693.x PMID: 22725712

[14] Kubiszewska J, Szyluk B, Szczudlik P, Bartoszewicz Z, Dutkiewicz M, Bielecki M, Bednarczuk T, Kostera-Pruszczyk A. Prevalence and impact of autoimmune thyroid disease on myasthenia gravis course. Brain Behav, 2016, 6(10):e00537. https://doi.org/10.1002/brb3.537 PMID: 27781146 PMCID: PMC5064344

[15] Mizutani S, Nakaoka K, Ohno K, Hayakawa M, Nishiyama M, Hasegawa J. [A case report of extended thymectomy in an elderly patient with myasthenia gravis associated with Hashimoto's disease]. Nihon Kyobu Geka Gakkai Zasshi, 1991, 39(2):228-231. PMID: 2033341

[16] Singer W, Sahay BM. Myasthenia gravis, Hashimoto's thyroiditis and pernicious anaemia. Br Med J, 1966, 1(5492):904. https:// doi.org/10.1136/bmj.1.5492.904 PMID: 20722214 PMCID: PMC1844391

[17] Daly JJ, Jackson E. Case of Hashimoto's disease with myasthenia gravis. Br Med J, 1964, 1(5385):748. https://doi. org/10.1136/bmj.1.5385.748 PMID: 14102022 PMCID: PMC 1815178

[18] Cheah JS, Tan AY. Coexistence of myasthenia gravis and Hashimoto's thyroiditis in a Chinese woman. Aust N Z J Med, 1972, 2(4):412-415. https://doi.org/10.1111/j.1445-5994.1972. tb03947.x PMID: 4512377

[19] Buzdugă CM, Costea CF, Dumitrescu GF, Turliuc MD Bogdănici CM, Cucu A, Dumitrescu N, Indrei L, Şapte E, Ciobanu Apostol DG. Cytological, histopathological and immunological aspects of autoimmune thyroiditis: a review. Rom J Morphol Embryol, 2017, 58(3):731-738. PMID: 29250648

[20] Sava A, Dumitrescu G, Haba D, Hodorog D, Mihailov C Şapte E. The Fahr syndrome and the chronic lymphocytic thyroiditis. Rom J Morphol Embryol, 2013, 54(1):195-200. PMID: 23529330

[21] Mohamed NSF, Mohd Zin F, Mohd Yusoff SS. An association of myasthenia gravis with Hashimoto's thyroiditis in a patient with a multinodular goiter. Malays Fam Physician, 2017, 12(2): 29-31. PMID: 29423128 PMCID: PMC5802774

[22] Yeh JH, Kuo HT, Chen HJ, Chen YK, Chiu HC, Kao CH. Higher risk of myasthenia gravis in patients with thyroid and allergic diseases: a national population-based study. Medicine (Baltimore), 2015, 94(21):e835. https://doi.org/10.1097/MD. 0000000000000835 PMID: 26020387 PMCID: PMC4616403

[23] Arellano AG, Salas MI, Rodríguez GN, Núñez MES Domínguez CLG. Fibrosis pulmonar idiopática, tiroiditis de Hashimoto y miastenia gravis: asociación extraordinaria [Idiopathic pulmonary fibrosis, Hashimoto's thyroiditis and myasthenia gravis: an extraordinary association]. Acta Med, 2017, 15(4):296-300. https://www.medigraphic.com/cgi-bin/ new/resumen.cgi?IDARTICULO=75896
[24] Blalock A, Harvey AM, Ford FR, Lilienthal JL Jr. The treatment of myasthenia gravis by removal of the thymus gland. Preliminary report. JAMA, 1941, 117(18):1529-1533. https:// doi.org/10.1001/jama.1941.02820440037009

[25] Utsugisawa K, Nagane Y. [Thymic abnormalities in patients with myasthenia gravis]. Brain Nerve, 2011, 63(7):685-694. PMID: 21747138

[26] Cornea R, Lazăr E, Dema A, Herman D. A nodular hyperplasia of the thymic epithelium (so-called microscopic thymoma). Rom J Morphol Embryol, 2009, 50(4):729-731. PMID: 19942974

[27] Cornea R, Cîmpean AM, Simu M, Cornea A, Suciu C, Raica M. Clinical, morphological and immunohistochemical characterization of a recurrent B1 type thymoma. Rom J Morphol Embryol, 2012, 53(3):639-643. PMID: 22990560

[28] Nikolic A, Djukic P, Basta I, Hajdukovic Lj, Rakocevic Stojanovic V, Stevic Z, Nikolic D, Bozic V, Lavrnic S, Lavrnic D. The predictive value of the presence of different antibodies and thymus pathology to the clinical outcome in patients with generalized myasthenia gravis. Clin Neurol Neurosurg, 2013, 115(4):432-437. https://doi.org/10.1016/j. clineuro.2012.06.013 PMID: 22770539

[29] Wang X, Laan M, Bichele R, Kisand K, Scott HS, Peterson P. Post-Aire maturation of thymic medullary epithelial cells involves selective expression of keratinocyte-specific autoantigens. Front Immunol, 2012, 3(March):19. https://doi.org/10.3389/ fimmu.2012.00019 PMID: 22448160 PMCID: PMC3310317

[30] Speck-Hernandez CA, Assis AF, Felicio RF, Cotrim-Sousa L, Pezzi N, Lopes GS, Bombonato-Prado KF, Giuliatti S, Passos GA. Aire disruption influences the medullary thymic epithelial cell transcriptome and interaction with thymocytes. Front Immunol, 2018, 9:964. https://doi.org/10.3389/fimmu.2018.00964 PMID: 29867946 PMCID: PMC5949327

[31] Watanabe N, Wang YH, Lee HK, Ito T, Wang YH, Cao W, Liu YJ. Hassall's corpuscles instruct dendritic cells to induce CD4+CD25+ regulatory $T$ cells in human thymus. Nature, 2005, 436(7054):1181-1185. https://doi.org/10.1038/nature 03886 PMID: 16121185

[32] Mikušová R, Mešt’anová V, Polák Š, Varga I. What do we know about the structure of human thymic Hassall's corpuscles? A histochemical, immunohistochemical, and electron microscopic study. Ann Anat, 2017, 211:140-148. https://doi.org/10.1016/ j.aanat.2017.02.006 PMID: 28279759

[33] Brinkane A, Bellamy J, Leroy-Terquem E, Levy R. [Thymoma and autoimmune thyroiditis. A case report]. Rev Pneumol Clin, 2003, 59(4):213-215. PMID: 14699299

[34] Costache II, Costea CF, Fotea V, Rusu VL, Aursulesei V, Al Namat R, Costache DA, Dumitrescu N, Buzdugă CM, Dumitrescu GF, Sava A, Bogdănici CM. Morphological and functional renovascular changes as cause of resistant arterial hypertension - case report and literature review. Rom J Morphol Embryol, 2018, 59(1):323-328. PMID: 29940645

[35] Costache II, Costea CF, Danciu M, Costan VV, Aursulesei V, Dumitrescu GF, Turliuc MD, Sava A. Amyloidosis - a rare cause of refractory heart failure in a young female. Rom $\mathrm{J}$ Morphol Embryol, 2017, 58(1):201-206. PMID: 28523319

[36] Zielinski M, Hauer L, Hauer J, Pankowski J, Nabialek T, Szlubowski A. Comparison of complete remission rates after 5 year follow-up of three different techniques of thymectomy for myasthenia gravis. Eur J Cardiothorac Surg, 2010, 37(5): 1137-1143. https://doi.org/10.1016/j.ejcts.2009.11.029 PMID: 20117014

[37] Lopomo A, Berrih-Aknin S. Autoimmune thyroiditis and myasthenia gravis. Front Endocrinol (Lausanne), 2017, 8:169. https://doi.org/10.3389/fendo.2017.00169 PMID: 28751878 PMCID: PMC5508005

\section{Corresponding authors}

Claudia Florida Costea, Associate Professor, MD, PhD, Department of Ophthalmology, Faculty of Medicine, Grigore T. Popa University of Medicine and Pharmacy, 16 University Street, 700115 laşi, Romania; Phone +40744972 648, e-mail: costea10@yahoo.com

Camelia Margareta Bogdănici, Professor, MD, PhD, Department of Ophthalmology, Faculty of Medicine, Grigore T. Popa University of Medicine and Pharmacy, 16 University Street, 700115 laşi, Romania; Phone +40722-507 913, e-mail: camelia.bogdanici@umfiasi.ro 